\title{
A FILIAÇÃO SOCIOAFETIVA E SUAS IMPLICAÇÕES ÀS DINÂMICAS FAMILIARES DOS DIAS ATUAIS NO BRASIL
}

\author{
Gabriela Pimentel Pessoa ${ }^{1}$ \\ Angélica Mota Cabral ${ }^{2}$
}

\begin{abstract}
Resumo: O Direito de Família brasileiro vinha tratando acerca da filiação socioafetiva até então de uma forma binária, com a prevalência da realidade afetiva sobre a biológica, mas as dinâmicas sociais estão a exigir novas soluções. Discutem-se as implicações do reconhecimento da filiação socioafetiva no Brasil e de que maneira esse instituto pode impactar nas relações familiares, principalmente no que diz respeito ao reconhecimento de uma multiparentalidade paralela. A atual jurisprudência tende a privilegiar a verdade afetiva sobre a verdade registral e biológica. A partir da discussão sobre o Provimento CNJ 63/2017 e as implicações para as famílias multiparentais paralelas, com base no método dedutivo, conclui-se que há uma necessidade clara de se elaborar teses mais apropriadas para dar conta dos casos de multiparentalidade, ainda pouco tratados pelo judiciário nacional de maneira clara e sedimentada.
\end{abstract}

Palavras-chave: Filiação socioafetiva; Multiparentalidade paralela; Direito das Famílias brasileiro; Verdade afetiva; Provimento CNJ 63/2017.

\section{THE SOCIO-AFFECTIVE FILIATION AND ITS IMPLICATIONS TO THE FAMILY DYNAMICS OF CURRENT DAYS IN BRAZIL}

\begin{abstract}
Brazilian Family Law was dealing with the socio-affective filiation recently in a binary fashion, with the prevalence of the affective truth over the biological one, but the social dynamics are demanding new solutions. This paper discusses the implications of the recognition of socio-affective filiation in Brazil and how this institute can impact on family relations, especially regarding the recognition of a parallel multi-parenthood. The current jurisprudence tends to privilege the affective truth about the registry and biological truth. Based on the discussion on the CNJ Provision 63/2017 and the implications for parallel multiparental families, based on the deductive method, it is concluded that there is a clear need to develop more appropriate theses to deal with cases of multi-parenthood, still treated by the national judiciary in a clear and settled manner.
\end{abstract}

Keywords: Socio-affective filiation; Parallel multi-parenthood; Brazilian Family Law; Affective truth; CNJ Provision 63/2017.

\footnotetext{
${ }^{1}$ Doutora em Direito pela UFRGS. Mestre em Direito pela UFC. Professora do Centro Universitário Estácio do Ceará. Advogada.

${ }^{2}$ Mestranda pelo Programa de Pós-Graduação em Direito da Universidade Federal do Ceará (PPGD/UFC). Bacharela em Direito pela UFC. Advogada.
} 


\section{INTRODUÇÃO}

A parentalidade/filiação socioafetiva aparece na sociedade atual como uma maneira de conformação das famílias às novas dinâmicas sociais que surgiram depois a concretização da possibilidade de realização de um novo casamento após o divórcio. É possível dizer que o paradigma inaugurado com a lei $6.515 / 77$ foi um marco no que diz respeito à aceitação de novas formas de constituição familiares.

Apesar da filiação socioafetiva não ser resultado unicamente da parentalidade que se inaugura com a realização de um novo casamento após o divórcio, é importante ressaltar que referida lei trouxe para a sociedade brasileira uma necessária reflexão sobre a inclusão de novos modelos de família, marco que foi capaz de fomentar o paradigma de inclusão e aceitação de novos modelos familiares que se experimenta hoje no judiciário.

A lei do Divórcio, a Constituição Federal de 1988, a E.C 66/2010, dentre outros aportes normativos, deram ensejo a uma verdadeira revolução no que diz respeito ao tratamento das questões familiares pelo judiciário. Enquanto que, antes de 1977, experimentou-se uma realidade social em que o objetivo do Estado, acerca das questões de Direito de Família era, principalmente, proteger o Casamento, a realidade atual aponta para uma constante e crescente necessidade de proteção dos vínculos familiares que derivam do afeto, independente de como são constituídos. Em outras palavras, o arcabouço principiológico que norteia a doutrina do Direito de Família atual visa proteger a família de uma forma mais plural e inclusiva, levando-se em consideração que os princípios da afetividade e da igualdade colocam toda e qualquer família sob o domo protetor do Estado Democrático de Direito.

Nesse contexto, a parentalidade socioafetiva se apresenta, tanto do ponto de vista prático, como teórico, como um novo paradigma necessário a ser enfrentado pelos estudiosos do Direito das Famílias. Enquanto que a tendência normativa atual é a de facilitar o reconhecimento de tal instituto, possibilitando, inclusive, a sua concretização por vias extrajudiciais, o que se observa na prática é que muitas pessoas desconhecem a própria existência de tal possibilidade.

Muitas vezes confundido pelo senso comum com o instituto da Adoção, ou até mesmo sendo tratada, de maneira errônea, como a relação existente entre padrastos e madrastas e seus enteados, a filiação socioafeitva ainda carece de tratamento mais acurado no que diz respeito à individualização de tal instituto, tão necessário para a convivência familiar saudável dos integrantes das novas conformações familiares. 
Com esse intuito, o presente artigo tem por objetivo fazer uma individualização do instituto jurídico da filiação socioafetiva de maneira a esclarecer as diferenças entre ele e demais institutos jurídicos que por vezes são confundidos em seus conceitos.

Além disso, pretende-se verificar como a aplicação prática da normatização relativa ao tema tem sido eficaz no que diz respeito a proteger as relações familiares alvo de tal instituto. Nesse sentido, o artigo divide-se em 3 momentos: o item 2, item inicial, tem o intuito de estabelecer um conceito claro e objetivo capaz de individualizar a filiação socioafetiva em suas peculiaridades. Em seguida, o item 3, busca analisar a normatização pertinente ao tema e sua aplicação do ponto de vista prático. Por último, o item 4 vem como o propósito de verificar a eficácia do instituto da filiação sociafetiva no que diz respeito à proteção das entidades familiares que precisam lançar mão desse instituto para manter suas relações.

Conclui-se que, conquanto o reconhecimento do instituto da filiação socioafeitva perfaz um marco na história do Direito de Família brasileiro, ainda carece de tratamento adequado, principalmente no que diz respeito ao seu reconhecimento pelo judiciário em toda amplitude de seus efeitos, desde a discussão sobre matérias menos controversas, como a necessidade de prestação de alimentos do "pai (ou mãe) socioafetivo", até matérias mais áridas e de difícil tratamento, como o reconhecimento do direito sucessório de pessoas que se encontram nesse tipo de conformação familiar.

Com base numa metodologia de caráter dedutivo, fez-se um levantamento bibliográfico e jurisprudencial acerca dos conceitos usualmente utilizados para tratar do tema para que se pudesse concluir que ainda é lacunoso e pouco satisfatório o aporte normativo existente para as mais diversas discussões envolvendo a filiação socioafetiva.

\section{O INSTITUTO DA FILIAÇÃO SOCIOAFEITIVA E SEU RECONHECIMENTO FACE À FILIAÇÃO BIOLÓGICA}

A Constituição Federal de 1988, trouxe consigo o princípio da igualdade da filiação (MADALENO, 2017), sepultando a diferenciação de tratamento entre os filhos havidos na constância do casamento e os havidos de formas diversas. Até o advento da Constituição, a diferenciação do tratamento entre os filhos colocava claro o escopo da Doutrina privatista de Direito de Família, no Brasil: era necessário que o Estado protegesse a instituição do casamento a despeito dos efeitos psicológicos que essa diferenciação pudesse gerar na formação individual dos filhos alvos dessa separação normativa insidiosa. Em outras palavras, 
o paradigma sobre filiação que se experimentava antes da Constituição de 1988 mitigava o interesse dos principais destinatários das normas: os filhos.

Importante marco é inaugurado com a Constituição de 1988 e os seus efeitos produziam um movimento de onda que resvalaram em diversos institutos do Direito de Família. A partir do momento que o Estado Democrático de Direito Brasileiro, trata de maneira igual os filhos, independente de como foram havidos, extingue-se do ordenamento jurídico as diferenciações entre os tipos de filiação, restando, quando muito, diferenciar os filhos apenas entre biológicos e não biológicos.

Do ponto de vista prático, significa dizer que a filiação, agora, reveste-se de novos contornos, onde os laços de afeto são tão importantes quanto a verdade biológica contida no exame de DNA. Esse reconhecimento pode ser observado em diversos julgamentos dos tribunais pátrios, os quais se pode observar que, independente do resultado do exame de DNA, ao magistrado cabe observar acuradamente as relações que se estabelece entre ascendentes e descendentes e como os vínculos são conformados.

Nesse contexto, é importante ressaltar que se busca, diferentemente da realidade vivenciada pré Constituição de 1988, a proteção dos principais destinatários das normas sobre filiação, quais sejam, os filhos.

Para o tratamento adequado das questões relativas à filiação, observa-se, quando é esse o contexto, que é necessário proteger o interesse do menor. Um exemplo claro desse tratamento inovador da jurisprudência nacional, é observado nos julgados onde se discute um vício de consentimento do homem que registra o filho de sua esposa, namorada ou companheira, sem saber ao certo a verdade biológica acerca dessa filiação.

Os tribunais têm entendido que, a depender do caso concreto, tal vício de consentimento não seria capaz de ensejar a desconstituição da relação de parentalidade levada a cabo pelo registro. A depender das circunstâncias, caso aquele menor reconheça como pai a pessoa que o registrou, não cabe ao juiz desconstituir os laços de afeto vivenciados pelo menor que entende aquele ser seu pai.

Nesse sentido, importa pouco o sentimento do adulto que se vê enganado, quando consente sua vontade de maneira viciada, restando mais necessário proteger o sentimento de afeto vivenciado pelo menor a ser protegido, problemática que será mais trabalhada no item final deste trabalho.

De toda sorte, é importante dizer que os vínculos de afeto são os principais indícios para o diagnóstico da existência de uma relação de parentalidade/filiação, socioafetiva, 
mesmo que do ponto de vista prático, pareça ser difícil estabelecer objetivamente o que vem a ser um vínculo afetivo protegido pelo Direito.

O que se observa nos dias atuais é uma tendência crescente de reconhecimento do que se convencionou chamar de "posse do estado de filho", revelando que para a doutrina e jurisprudência pátria, mais vale a constatação da real situação fática de determinada relação parental do que a prova da filiação biológica constituída por meio de um exame de DNA.

Nesse sentido, é importante diferenciar, principalmente dois institutos que são constantemente confundidos com a filiação socioafetiva: a adoção e as relações de parentesco constituídas por afinidade em razão do casamento e da união estável.

\subsection{A adoção e sua diferenciação do instituto da parentalidade socioafetiva}

Trabalhar os conceitos que se ligam a ideia de socioafetividade se faz necessário principalmente para que na aplicação prática, possa-se adotar corretamente o instituto que mais se adequa ao caso concreto. Em outras palavras, é percebido que o senso comum ainda carrega a ideia de que a parentalidade socioafetiva se identifica com o instituto da adoção o que faz com que, muitas vezes os indivíduos deixem de buscar solução para suas demandas individuais por carregarem a dúvida de que entrarão em um processo que já ficou conhecido por ser demasiadamente longo e oneroso.

Encarando-se meramente pelo viés científico, tal problemática parece não representar maiores entraves uma vez que restaria resolvida com uma simples apreciação dogmática dos institutos a fim de individualiza-los da maneira correta. Na prática, entretanto, não é a realidade que está posta.

Muitas pessoas, mesmo desenvolvendo claras relações de parentalidade socioafetiva, parecem não compreender o real alcance do significado do instituto. Em outras palavras, o homem médio costuma acreditar que os efeitos advindos das relações de parentalidade só existiriam em razão da vontade expressa dos envolvidos nessa relação em perquirir o caminho jurídico da Adoção.

De toda maneira, é necessário demonstrar que, diferentemente da Adoção, em que os envolvidos expressam uma vontade clara perante o Estado de instituírem uma relação de filiação com um filho não biológico, na parentalidade socioafetiva, essa relação pode-se desenvolver a despeito clara manifestação de vontade. Pode-se dizer que as relações de parentalidade socioafetiva podem nascer e desenvolver-se distantes da apreciação do Estado, 
o que não o impede de, ocasionalmente, ser chamado a dar uma decisão acerca da existência ou não daquela filiação.

Os laços de afetividade na parentalidade socioafetiva acontecem a despeito da chancela estatal e, muito embora haja uma tendência cada vez maior do Estado acompanhar de perto essas relações, seja do ponto de vista da atuação judicial no reconhecimento de sua existência, seja do ponto de vista do reconhecimento registral simplificado dessas relações (como se pôde observa no provimento no. 63/2017 do CNJ), essa apreciação só torna jurídico o que de fato já existia há tempos.

O foco do presente trabalho não é pormenorizar o instituto da Adoção, mas tão somente, conseguir demonstrar que a falta de conhecimento acerca de ambos os institutos aqui analisados faz com que as pessoas tratem as relações de parentalidade socioaftivas com menos cuidado do que deveriam tratar. Não é irrelevante o número de pessoas que se coloca na situação de pai ou mãe a olvidar o que isso representa, principalmente quando se está falando de uma relação de filiação com um menor.

Os efeitos da filiação socioafetiva, tais como a obrigação alimentar que dela deriva, parecem não fazer parte do conhecimento do senso comum, que parece crer, ao menos nos dias atuais, que tais efeitos só correriam em uma situação de Adoção. É importante ressaltar que a Adoção, rompe com o vínculo de parentalidade anterior, o que não é o mesmo efeito observado no reconhecimento da filiação socioafetiva, a qual, inclusive, prevê a existência dois pais, ou duas mães no registro.

Talvez muito do que se vê na sociedade em relação a essa problemática advenha da banalização do que se convencionou chamar de "adoção à brasileira". A história parece familiar a muitos brasileiros. Pais que, mesmo sem ter certeza da condição biológica do feto que carrega uma companheira ou namorada, registram o filho na ocasião de seu nascimento em seu nome, como se pai fosse. A situação narrada já fora amplamente discutida pelos tribunais brasileiros que, em sua maioria, não procedem a anulação do registro caso se verifique o desenvolvimento de laços de afeto entre os envolvidos.

Menos comum nos dias atuais, mas ainda existente, é a situação em que uma mulher registra um bebê deixado em sua porta como se seu fosse. O tratamento dos tribunais confirma o entendimento que os laços de afeto não poderiam ser defeitos nesse caso por uma impropriedade no ato registral da criança que, mesmo que tenha sido feito de má-fé, não anula o sentimento que aquele menor nutre em relação a sua mãe "adotiva". 
O reconhecimento das relações afetivas por meio nos tribunais, nesses casos, leva os indivíduos a crer que a existência da relação socioafitva está diretamente ligada ao ato de registrar ou de adotar, o que não parece ser a compreensão mais correta desta problemática. $\mathrm{O}$ que se apresenta na análise de tais decisões é uma prevalência cada vez maior da verdade afetiva sobre a verdade registral ou biológica. Isso quer dizer que, no caso concreto, o magistrado cada vez mais tem se preocupado em verificar a existência de laços de afeto, a despeito do que se tem como registro civil, ou exame de DNA.

Isso não quer dizer que o tratamento do instituto da parentalidade socioafetiva esteja perto de ser reconhecido em sua importância, inclusive, pela população. Diuturnamente os escritórios de advocacia têm recebido cada vez mais casos de pessoas que desejam tornar oficial as suas relações de parentalidade socioafetiva. É cada vez mais difícil, nos dias atuais, uma pessoa poder exercer funções típicas de pais sem que haja uma consubstanciação registrada dessa condição.

Pode-se se citar como exemplo, a necessidade de estabelecer contato com as escolas dos menores, acessar prontuários médicos, atividades que só podem ser exercidas por quem detenha o poder parental. Muitas são as pessoas que intentam desenvolver essas atividades sem maiores entraves, mas esquecem de contemporizar que concomitantemente com o bônus de se exercer a função de pais, advém também o ônus inerente a ela.

A parentalidade socioafetiva é um vínculo que, uma vez estabelecido, não pode ser desfeito e essa condição demanda maior esclarecimento por parte da população. O pai ou mãe socioafetivos permanecem com essa atribuição a despeito do que possa acontecer com os relacionamentos conjugais. É importante ressaltar que o reconhecimento da parentalidade sociafetiva é um vínculo tão forte quanto o de qualquer outra filiação, até mesmo porque, o Direito Brasileiro não diferencia mais classes de filhos.

Parece óbvio, mas o homem médio que deseja ser pai socioafetivo encara com estranheza o esclarecimento de que, mesmo que termine o seu relacionamento com a genitora do menor, a socioafetividade não cessa. Essa informação faz com quem muitas pessoas repensem a decisão de tornar oficial o reconhecimento da filiação.

Isso não quer dizer que o menor, não poderia, mesmo que representado, perquirir esse reconhecimento, uma vez que ele estivesse posto de fato. Como já foi explicitado, as relações de afeto nascem e se desenvolvem a despeito da chancela do Estado e por mais que num determinado momento, por razões íntimas, se tente negar perante o juízo a existência desse 
afeto, tem-se percebido cada vez mais que a vontade do pai ou mãe socioafetivos não é elemento determinante para o reconhecimento da relação, buscando-se sempre o melhor interesse do menor.

\subsection{A condição de madrasta e padrasto e sua diferença entre parentalidade socioafetiva.}

Chegou-se até aqui com o intuito de colocar de maneira pormenorizada a existência de uma relação, reconhecida pelo Direito de Família como relação estabelecida com direitos e deveres (principalmente de caráter moral) e, agora, muito confundida com a parentalidade socioafetiva: as relações dos padrastos e das madrastas com seus enteados.

O Código Civil deixa claro que existe relação de parentesco por afinidade entre os filhos dos cônjuges e seus respectivos consortes. Conquanto essa relação não expresse exercício do poder familiar, é uma relação que deve ser reconhecidamente tratada como uma relação familiar, na qual os envolvidos vivenciam seus efeitos de maneira concreta. Um exemplo claro é o impedimento de se estabelecer matrimônio entre padrastos e madrastas e seus enteados, mesmo depois de findo o casamento.

A despeito das críticas que doutrinariamente se possa fazer a esses impedimentos (DIAS, 2013), fica claro que código civil quis enaltecer as relações entre padrastos e madrastas e seus enteados como relações tipicamente familiares. O papel de padrasto e madrasta denota, principalmente, o dever de cuidado e atenção com os enteados, sendo respeitados os papéis dos pais, principalmente quando se está falando de menores.

A confusão dos papeis de padrastos e madrastas e pais socioafetivos, nos dias atuais, se faz mais presente. As relações dinâmicas fazem com que as pessoas estreitem laços de afeto de maneira menos cuidadosa, restando difícil a dissociação entre a figura de um padrasto e de um pai socioafetivo, por exemplo.

Pouco se vê pormenorização conceitual acerca dos papeis de um e de outro no universo jurídico. Conquanto os profissionais da psicologia possam delimitar melhor essas relações, aparentemente os profissionais do Direito não parecem ser capazes de tratar suas diferenças de maneira correta, algo que significaria, inclusive, uma maior proteção ao instituto da socioafetividade.

Um padrasto ou madrasta vivencia um papel importante na vida de seu enteado ou enteada e da convivência familiar como um todo, o que não quer dizer que esse papel, necessariamente, se identifique com a representação afetiva que ocupa um pai ou uma mãe. Existe uma diferença longínqua entre querer estabelecer comunhão de vida comum com o 
genitor de uma criança e ter a vontade de ser genitor. Essa questão é extremamente relevante quando se coloca, às pessoas que pleiteiam o registro socioafetivo de parentalidade, que esse tipo de filiação é irrevogável, tanto quando a que se constitui por adoção, infelizmente, algo que não parece se de amplo conhecimento por parte da população.

Nesse sentido, parece cada vez mais tênue a linha que separa os papéis de padrastos e madrastas e pais socioafetivos, ainda mais quando se fala de um contexto cultural onde tornase cada vez mais provável a coabitação entre padrastos e madrastas e seus enteados. Frise-se que o intuito do presente trabalho não é desvalorizar o marco histórico do reconhecimento do afeto em prevalência da realidade biológica, mas tão somente, ressaltar que existe uma necessidade evidente de se evitar a confusão de papéis, ainda mais quando se analisa contexto familiares em que os atores envolvidos são menores.

Mais difícil ainda é fazer a particularização da parentalidade socioafetiva quando o contexto analisado é o de uma possível união estável. A jurisprudência nacional tem sido precisa ao reconhecer que uma relação de filiação socioafetiva prevalece sob a biológica, mas esse reconhecimento é menos complexo quando se está analisando uma situação em que o pai biológico não tem convivência com o menor em questão.

$\mathrm{O}$ provimento no. 63 do $\mathrm{CNJ}$, que tem a pretensão de desburocratizar o reconhecimento da filiação socioafetiva, procedendo o registro da filiação sem a necessidade de processo judicial, constitui um marco no que diz respeito à proteção e garantia desse estilo de filiação e coloca, textualmente, a irrevogabilidade desse reconhecimento, senão vejamos:

Art. 10. O reconhecimento voluntário da paternidade ou maternidade socioafetiva de pessoa de qualquer idade será autorizado perante os oficiais de registro civil das pessoas naturais.

$\S 1^{\circ}$ O reconhecimento voluntário da paternidade ou da maternidade será irrevogável, somente podendo ser desconstituído pela via judicial, nas hipóteses de vício de vontade, fraude ou simulação.

Conquanto o provimento coloque a possibilidade de desconstituição do registro por via judicial, é importante ressaltar que os tribunais brasileiros têm orientado suas decisões, sempre contemplando o princípio do melhor interesse do menor. Isso quer dizer que, independentemente da existência de vício de vontade, fraude ou simulação, no contexto jurisprudencial atual, é provável que o registro não reste desconstituído caso haja a constatação de uma relação de afetividade entre os pais que constam nos registros e seus respectivos filhos.

Essa relação afetiva é o principal objeto de análise do presente estudo. Uma vez que o provimento no. 63 e a jurisprudência nacional enaltecem a filiação afetiva a ponto de a 
colocarem em prevalência sobre a filiação biológica e registral, tornar-se-á cada vez mais corriqueiro a existência de menores com dois pais ou duas mães no registro e os efeitos desse reconhecimento ainda são pouco experimentados pela sociedade atual.

É importante a reflexão sobre o que representa a existência de dois pais ou duas mães do registro de nascimento. Em termos práticos, o que significa do ponto de vista da obrigação alimentar? E em relação ao direito sucessório? Pessoas que tem dois pais ou duas mães terão também dever alimentar com ambos os constantes no registro no caso de velhice? Os menores que constam com dois pais no registro devem obediência a qual em caso de conflito de interesses? Esses e outros desdobramentos são relevantes e demandam uma necessária reflexão.

\section{O TRATAMENTO NORMATIVO RELACIONADO À FILIAÇÃO SOCIOAFETIVA NO BRASIL E SUAS IMPLICAÇÕES PRÁTICAS}

A normatização pertinente ao tema da filiação sociafetiva no Brasil ainda acontece, eminentemente, por via jurisprudencial, tendo sido o STJ precursor da construção dessa categoria de filiação (CALDERÓN, 2017, p. 214).

Conquanto o provimento no. 63 do CNJ tenha esclarecido, para os devidos fins, como se dá o reconhecimento da filiação socioafetiva extrajudicialmente, o termo fora cunhado de maneira doutrinária, quando ao se deparar com alguns fenômenos típicos do Direito Familiar ("adoção à brasileira", guarda compartilhada, entre outros) os doutrinadores viram a necessidade de delimitar os contornos de um instituto que, há muito, já acontecia na prática, mas era pouco reconhecido do ponto de vista jurídico.

Assim, a concretização do instituto da filiação sociafetiva aparece como uma resposta a problemáticas postas em razão da complexidade das relações familiares dos dias atuais, mormente as relações familiares brasileiras. Ela surge como solução menos drástica no que diz respeito ao não desfazimento dos laços familiares anteriores para a sua constituição. Em outras palavras, enquanto que no instituto jurídico da adoção era necessário romper com o vínculo de parentalidade anterior, no reconhecimento da filiação socioafetiva, isso não é necessário, e é possível fazer constar no registro o nome de até dois pais e/ou até duas mães.

Esse formato parece muito mais adequado a situações de várias famílias recompostas brasileiras (DIAS, 2013), tendo em vista que, na situação em que padrastos e madrastas participam ativamente da criação e educação dos filhos, é importante que pudessem exercer o poder familiar de maneira mais satisfatória. 
Entretanto, em muitos casos, os pais biológicos/registrais, ainda acompanham o crescimento dos filhos, não desejando romper qualquer vínculo de parentalidade com eles. $\mathrm{O}$ que se busca, nesses casos, portanto, é a possibilidade do exercício do poder familiar de maneira paralela, em que pais biológicos e afetivos poderiam conviver lado a lado e participar conjuntamente da promoção do desenvolvimento dos filhos.

\subsection{O exercício do poder familiar e as dificuldades encontradas pelos pais socioafetivos}

\section{não registrados}

O poder familiar é o conjunto de atribuições dadas aos pais para que possam melhor desempenhar a missão de guardar, defender e educar os filhos a fim de formá-los de maneira a melhor desenvolver suas potencialidades para viver e agir em sociedade. O poder familiar visa, primordialmente, a manutenção do melhor interesse do menor e deve ser exercido de maneira a proteger a infância e a juventude.

O Artigo 1.631 do Código Civil prescreve, textualmente, que cabe aos pais o poder familiar:

Art. 1.631. Durante o casamento e a união estável, compete o poder familiar aos pais; na falta ou impedimento de um deles, o outro o exercerá com exclusividade.

Parágrafo único. Divergindo os pais quanto ao exercício do poder familiar, é assegurado a qualquer deles recorrer ao juiz para solução do desacordo

É de se compreender que no contexto histórico da entrada do Código Civil de 2002 em vigor este ainda não trouxesse previsto a regulamentação do instituto da paternidade socioafetiva. Apesar de factualmente ser algo possível desde sempre, foi preciso que a sociedade pudesse se tornar mais inclusiva às novas possibilidades familiares que nasceram a partir do paradigma Constitucional da igualdade inaugurado em 1988.

O tempo foi determinante para que a sociedade pudesse internalizar o fenômeno das famílias reconstituídas (mosaicas) (DIAS, 2013). De toda forma, não se pode observar no Código Civil, nada que impeça a concretização do instituto da filiação socioafetiva, ainda mais se o Código for interpretado lado a lado à Constituição, onde se encontra princípios que auxiliam o intérprete nesse sentido.

Os princípios, como mandamentos de otimização do sistema jurídico (ALEXY, 2008), ajudam a integrar ao ordenamento jurídico a possibilidade de reconhecimento de filiação socioafetiva como instituto do ordenamento jurídico dos dias atuais. É inegável que os dispositivos do Código Civil devem contemplar os princípios do melhor interesse do menor, da dignidade da pessoa humana, da igualdade da filiação e da isonomia entre homens e 
mulheres. De acordo com esses aportes normativos, a filiação socioafetiva não só é desejável como necessária para a concretização da justiça material desejada pelo Direito.

Se a realidade posta coloca como nova dinâmica familiar a existência de arranjos em que existe mais de um indivíduo a exercer o papel de pai ou de mãe e, contanto que em suas ações, coloquem o princípio do melhor interesse do menor como horizonte norteador, é imprescindível que se dê a esses indivíduos a oportunidade do exercício de suas funções maternas e paternas paralelamente, para que isso se reverta, inclusive, em benefício do menor.

É sabido que situações corriqueiras do cotidiano exigem a comprovação do poder familiar para que possam ser desenvolvidas. O próprio ato de matricular o filho em uma escola, ou levá-lo ao médico, situações banais, mas que podem representar enorme constrangimento, tanto ao menor como ao pai/mãe socioafetivo quando esses se encontram impedidos de desenvolvê-los pela ausência do registro da realidade fática no documento civil.

O provimento no. 63 do $\mathrm{CNJ}$ apareceu, num primeiro momento, como solução não burocrática para findar esse problema. Com o seu advento no ano de 2017, muitos pais e mães socioafetivos não tardaram em buscar a consultoria de escritórios especializados em Direito de Família a fim de assegurar-se que poderiam realizar o reconhecimento registral de sua condição sem maiores empecilhos. Num primeiro momento, foi essa a orientação passada. Caso os genitores estivessem de acordo e providenciassem documentalmente o seu aceite ao reconhecimento da filiação socioafetiva do menor, seria possível proceder a inclusão de um segundo pai, ou uma segunda mãe no registro do menor.

Entretanto essa compreensão do provimento não durou muito. $\mathrm{O}$ próprio $\mathrm{CNJ}$, ao pronunciar-se sobre o tema, resolveu que a inclusão de dois pais ou duas mães, vivos, no registro demandaria, ainda, processamento judicial. É o que se lê em matéria publicada pelo IBDFAM (2017):

\footnotetext{
Ainda conforme a matéria publicada pelo Conselho Nacional de Justiça, o reconhecimento da paternidade ou maternidade socioafetiva em cartório de dois pais ou de duas mães ou mais não poderá ser feito extrajudicialmente. Isso significa que em casos como, por exemplo, o reconhecimento de uma mãe biológica e socioafetiva em uma mesma certidão de nascimento só será possível mediante uma decisão judicial.
}

Assim permanecem sendo discutidos judicialmente os casos em que a paternidade socioafetiva é exercida, paralelamente, por dois pais ou duas mães. Firma-se o entendimento, no presente artigo, que parece correta a orientação do CNJ ao confirmar a necessidade de apreciação do magistrado dos casos acima descritos. 
Ocorre que é imprescindível que o Estado, através da participação do Ministério Público e do Poder Judiciário, possa ratificar a conformidade do caso concreto em análise com o princípio do melhor interesse do menor. Não se pode, com a justificativa da morosidade do judiciário, abrir mão dessa verificação em nome de uma pretensa celeridade, que pode, muitas vezes, apresenta-se nociva ao menor.

O que é desejável é que, institucionalmente, o judiciário possa criar divisões de desburocratização de situações desse tipo, como já ocorre, por exemplo, com as Seções de Autorização de Viagem dos Juizados da Infância e da Juventude ${ }^{3}$. Se existirem os requisitos da existência a afetividade entre o pretenso pai ou mãe e o aceite de ambos os genitores, parece razoável que se crie uma divisão, ou Seção, das Varas da Infância e da Juventude para o tratamento célere desses casos. Algo que não aconteceria à revelia da apreciação Estatal, mas também não apresentaria o temor do vilipêndio do interesse do menor.

\section{A PARENTALIDAdE SOCIOAFETIVA E AS IMPLiCAÇÕES FÁtiCAS DO INSTITUTO}

Conquanto seja desejável que cada vez mais famílias possam ter a oportunidade de experimentar a vivência da filiação socioafetiva, ainda existem dúvidas sobre qual é a extensão do alcance dos efeitos jurídicos desse reconhecimento. O STJ e outros tribunais vem, ao longo do tempo, demonstrando uma vinculação maior ao interesse de privilegiar a filiação socioafetiva. É o que demonstra uma pesquisa realizada por Simone Tassinari Cardoso no ano de 2016, onde se lê:

No STJ é possível identificar o privilégio da realidade socioafetiva sobre a realidade do vínculo biológico. Em $76 \%$ das decisões houve reconhecimento e/ou preservação do vínculo socioafetivo frente ao vínculo biológico. Em sentido oposto, apenas $23 \%$ reconheceram a preponderância do vínculo biológico. (CARDOSO, 2016, p.22)

Embora os tribunais estejam demonstrando uma tendência clara de fazer prevalecer a verdade socioafetiva sobre a registral e a biológica, o que se vê sendo corriqueiramente discutido não é a existência paralela de uma parentalidade (onde pai ou mãe socioafetivos desempenham concomitantemente seus direitos e deveres de pais com os de origem biológica)

\footnotetext{
${ }^{3}$ No Tribunal de Justiça do Estado do Ceará os pedidos de autorização de viagem acontecem em setor próprio do Juizado da Infância e da Juventude, algo que pôde desburocratizar sobremaneira a vida dos genitores que desejavam viajar a lazer com seus filhos, mas não podiam, pois, muitas vezes, encontravam negatória sem justificativa de ex-cônjuges insatisfeitos com a separação. A forma desburocratizada de requerer essa autorização é um bom exemplo de como se pode transitar entre a extrajudicialidade dos cartórios e a morosidade do judiciário (TJCE, 2017).
} 
mas tão somente uma discussão onde se busca verificar quem é o único detentor da afetividade, a qual será reconhecida privilegiada.

Isso quer dizer que os casos em que os tribunais brasileiros firmaram a escolha pela manutenção da afetividade colocam a situação fática em que existe apenas um pai ou mãe com a posse de estado de filho. Nesse sentido, os magistrados têm decidido que quem detém essa posse é que também tem obrigações de ordem alimentar, são eles que detêm o poder familiar e por consequência, é essa relação que também gera efeitos sucessórios.

Parece justo esse posicionamento, mas conquanto o tratamento do judiciário, nesses casos, tenha sido adequado, não se têm observado muitas discussões sobre os efeitos do reconhecimento da filiação socioafetiva nos casos da multiparentalidade paralela. Entende-se aqui por multiparentalidade paralela, aquela situação em que dois pais ou duas mães vivem na posse do estado de filho de maneira concomitante. O menor recebe auxílio para sua vida e desenvolvimento tanto do seu genitor, quanto de uma pessoa que não tem identidade genética com ele.

Então, é possível que nos próximos meses ou anos, podemos estar discutindo a possibilidade da manutenção de pensões alimentícias a serem prestadas por mais de um indivíduo a figurar no papel de pai ou mãe, que as pessoas possam usufruir de direitos sucessórios advindos dessa dupla parentalidade, poder-se-á discutir guarda compartilhada com mais de um pai ou mãe, dentre outras coisas ainda não pensadas.

É por isso que se reafirma o posicionamento de que é interessante que os casos de multiparentalidade em razão da socioafetividade possam sempre ser discutidos no judiciário, por menos complexos que sejam. Esse cuidado tem o intuito de minimizar a possibilidade de tornar demasiadamente complexa a vida de menores que ainda não sabem direito como lidar com as próprias emoções.

A despeito de se defender que afeto e carinho nunca são demais, o desamor e o conflito em excesso podem causar traumas irreparáveis à vida de uma criança e talvez, não seja desejável que a situação da multiparentalidade aconteça em ambiente de descordo familiar.

Se pudéssemos experimentar um judiciário equipado para lidar com as situações disruptivas familiares de uma maneira mais humanizada, de modo que as pessoas efetivamente pudessem tornar-se participantes das tomadas de decisão, talvez não houvesse, inclusive questionamento sobre ser este o âmbito mais apropriado a lidar com as questões dessa ordem. 
Ocorre que o próprio judiciário parece não se entender no que diz respeito à compreensão do que efetivamente representa o reconhecimento da existência de parentalidades paralelas. Embora o STF já tenha deixado claro que essa é uma possibilidade conformação familiar e a reconhece claramente no RE 898.060/SC. Rel. Min. Luiz. Fux., parece o ter feito de maneira equivocada ao tratar como multiparentalidade paralela um caso em que a autora da ação só tomou conhecimento aos 19 anos de idade da existência do pai biológico, tendo passado uma vida inteira desenvolvendo um relacionamento socioafetivo com outro pai, constante no registro, algo que jamais foi negado nos autos do referido processo.

O pedido inicial da autora consistia no reconhecimento da paternidade e consequentemente, seus referidos reflexos (alteração do registro, reconhecimento de direito sucessório, possibilidade de se pleitear alimentos, entre outros), mas o STF entendeu por bem reconhecer e manter ambas as paternidades. Assim a tese estabelecida na Repercussão Geral 622 do STF (2018) traz a seguinte redação.

A paternidade socioafetiva, declarada ou não em registro, não impede o reconhecimento do vínculo de filiação concomitante, baseada na origem biológica, com os efeitos jurídicos próprios.

O caso em comento deixa claro o posicionamento do STF em afirmar a existência da multiparentalidade, entretanto, os tribunais até então vinham tratando os casos como o caso que deu ensejo à edição da Repercussão Geral 622 de maneira bastante diversa. É importante ressaltar que aqui não se está falando de um exercício de paternidade, ou de poder familiar que acontece concomitantemente, mas tão somente o reconhecimento da filiação registral e biológica de maneira que uma não se sobreponha a outra.

O que se vê, por exemplo, no julgado do Tribunal de Justiça do Estado do Paraná (PARANÁ, 2002), é uma compreensão completamente diversa. É o que se lê:

No confronto entre a verdade biológica, atestada no exame de DNA, e a verdade
socioafetiva, decorrente da denominada 'adoção à brasileira' e que perdura por
quase quarenta anos, há que prevalecer a solução que melhor tutele a dignidade da
pessoa humana. [...]" (TJ/PR. Relator: Des. Accacio Cambi. Julgado em 12.12.2001.
DJ/PR 04.03.2002).

Esses entre outros posicionamentos firmados ao longo do tempo demonstravam que os tribunais brasileiros tinham uma tendência clara em não reconhecer a multiparentalidade paralela quando havia, faticamente, o exercício de apenas um poder familiar. Nos casos onde apenas uma pessoa detém a posse do estado de filho, é essa pessoa que deve ser reconhecida como usufruidora dos efeitos do poder familiar. 
Não é o caso do julgamento do STF anteriormente referido. Os autos do processo demonstram que havia o exercício de uma paternidade socioafetiva que perdurou durante 19 anos, algo que jamais foi negado. Isso quer dizer que autora do processo, enquanto menor, pôde usufruir de uma relação socioafetiva com um pai, o qual cumpriu seu papel durante esse período de tempo.

Se o STF tivesse seguido a tendência dos tribunais nacionais até então, teria fixado a existência apenas da paternidade socioafetiva, o que não quer dizer que a autora não pudesse ter a paternidade biológica declarada para efeitos de conhecimento da sua origem genética e por assim dizer, ter assegurado um direito de personalidade.

O que aqui se está a defender é que as situações que se apresentam nos casos concretos de multiparentalidade exercida paralelamente por dois pais ou duas mães não é essa que deu ensejo à Repercussão Geral 622 e sim, aquela em que é existem duas pessoas desejando exercer o poder familiar para todos os fins, com direitos e responsabilidades, algo que se vê cada vez mais presente nos dias atuais.

Conquanto se possa pensar que o julgamento do STF abriu as portas para compreensão de que é possível a existência de uma multiparentalidade paralela que acontece no mesmo período de tempo, não é precisamente o que foi apreciado no julgamento em comento.

De toda forma, o que se pode argumentar, frente a essa Repercussão Geral é que existe sim a possibilidade do exercício do poder familiar por dois pais e duas mães ao mesmo tempo e que esse exercício gerará todos os efeitos dele decorrentes, tais como a possibilidade de se ter a prestação alimentar exigida aos pais socioafetivos e aos biológicos ao mesmo tempo.

Além disso, vislumbra-se também a possibilidade de haver discussões acerca de uma guarda que poderia ser compartilhada por até 4 pessoas (nos termos do art. 14 do provimento 63 do CNJ). E, por fim, é possível também argumentar que o posicionamento do STF consolidou o entendimento de que um indivíduo pode fazer jus a mais de dois direitos sucessórios em razão da ascendência em linha reta em primeiro grau (herdando dos seus pais e mães genéticos e também dos socioafetivos). 


\section{CONCLUSÕES}

Conclui-se, portanto, que os desdobramentos da Repercussão Geral 622 e do provimento no. 63/2017 do CNJ ainda estão longe de serem sistematizados pelos nossos tribunais. É possível crer que, em determinadas questões, mormente as discussões acerca de interesses de menores, não vão ser tão facilmente resolvidas por tratar-se de situações fáticas muito mais complexas que os referidos aportes normativos são capazes de dar conta.

É interessante perceber que o STF, de maneira mais ou menos despretensiosa, foi capaz de dar resposta à uma questão que já há muito tempo permeava o judiciário, mas era tratada de maneira completamente diferente. Entretanto, o fez em um caso concreto em que não envolvia uma discussão sobre interesses de menores e de uma maneira tangencial, acabou tratando acerca do tema da multiparentalidade paralela que acontece diuturnamente nos lares das famílias brasileiras que experimentam a dinâmica das famílias reconstituídas.

Independentemente de estar se defendendo a prevalência da manutenção das relações de afeto sobre quaisquer outras relações, é importante colocar em destaque que os desdobramentos desse posicionamento podem tornar a vida de menores muito mais complexas do que esses infantes ainda estariam aptos a vivenciar

Imaginar que um menor em idade escolar precise vivenciar um processo de disputa de guarda em que 4 pessoas não conseguem entrar em consenso acerca das suas atribuições e deveres enquanto detentores do poder familiar parece ser ferozmente desastroso e, a partir do momento que se conclui que a multiparentalidade, exercida concomitantemente, é uma possibilidade, as atenções para esses casos devem ser redobradas a fim de se evitar danos irreparáveis a vida de crianças e jovens.

A conclusão que se chega aqui não é a de que a multiparentalidade paralela seja algo não desejável, mas tão somente que a sistematização acerca do tratamento jurídico sobre esse assunto ainda não está completa, tendo em vista que o julgamento do STF deu-se em um caso concreto peculiar e diferente do que se está querendo colocar aqui.

Ainda será preciso percorrer um longo caminho no sentido de sedimentar e sistematizar essa compreensão e a Repercussão Geral 622, bem como o provimento no. 63/17 do CNJ apenas inauguraram as discussões acerca do tema. Tendo em vista que o caso concreto que deu ensejo a esse posicionamento não contempla todos os casos de multiparentalidade, ainda é preciso se fazer uma análise do caso concreto para se fazer considerações que visem a proteção de diversos princípios do Direito. 


\section{REFERÊNCIAS}

ALEXY, Robert. Teoria dos direitos fundamentais. Tradução de Virgílio Afonso da Silva. São Paulo: Malheiros, 2008. (teoria \& direito público, 1)

DIAS, Maria Berenice. Manual de direito das famílias. 9. ed. São Paulo: Revista dos Tribunais, 2013.

CALDERÓN, Ricardo. Princípio da afetividade no direito de família. 2. ed. Rio de Janeiro: Forense, 2017.

CARDOSO, Simone Tassinari. Notas sobre a parentalidade biológica e socioafetiva: do direito civil moderno ao contemporâneo. Civilistica.com, Rio de Janeiro, ano 5, n. 1, p. 1-29, 2016. Disponível em: <http://civilistica.com/wp-content/uploads/2016/07/Cardosocivilistica.com-a.5.n.2.2016.pdf>. Acesso em: 8 set. 2018.

CEZAR-FERREIRA, Verônica A. da; MACEDO, Rosa Maria Stefanini. Guarda compartilhada: uma visão psicojurídica. Porto Alegre: Artmed, 2016.

CNJ [Conselho Nacional de Justiça]. Provimento $\mathbf{n}^{\mathbf{0}}$ 63, de 14 de novembro de 2017. Institui modelos únicos de certidão de nascimento, de casamento e de óbito, a serem adotadas pelos ofícios de registro civil das pessoas naturais, e dispõe sobre o reconhecimento voluntário e a averbação da paternidade e maternidade socioafetiva no Livro "A" e sobre o registro de nascimento e emissão da respectiva certidão dos filhos havidos por reprodução assistida. Brasília: CNJ, 2017. Disponível em: <http://www.cnj.jus.br/busca-atosadm?documento=3380>. Acesso em: 8 set. 2018 .

IBDFAM [Instituto Brasileiro de Direito de Família]. Especialistas avaliam Provimento que autoriza reconhecimento da socioafetividade em cartórios. IBDFAM, Belo Horizonte, Notícias, 22 nov. 2017. Disponível em: $<$ http://www.ibdfam.org.br/noticias/6504/Especialistas+avaliam+Provimento+que+autoriza+r econhecimento+da+socioafetividade+em+cart\%C3\%B3rios>. Acesso em: 8 set. 2018.

MADALENO, Rolf. Direito de família. 7. ed. Rio de Janeiro: Forense, 2017.

PARANÁ. Tribunal de Justiça do Estado do Paraná. Acórdão 108.417-9. Relator Des. Accácio Cambi, julgado em: 12 dez. 2001. Dário de Justiça do Estado do Paraná, Curitiba, 4 fev. 2002.

STF [Supremo Tribunal Federal]. Teses de Repercussão Geral. Brasília, DF: STF, 2018. Disponível em: <http://www.stf.jus.br/portal/jurisprudenciaRepercussao/abrirTemasComRG.asp>. Acesso em: 8 set. 2018.

TJCE [Tribunal de Justiça do Estado do Ceará]. Fórum Clóvis Beviláqua emite 151 autorizações de viagens no primeiro trimestre do ano. TJCE, Notícias, 03 abr. 2017. Disponível em: <https://www.tjce.jus.br/noticias/forum-clovis-bevilaqua-emite-151autorizacoes-de-viagens-no-primeiro-trimestre-do-ano/>. Acesso em: 8 set. 2018. 